\title{
Analisa Aspek Non-Finansial Pemanfaatan Virtual Reality Technology Menggunakan Domain Teknologi Pada Metode Information Economics
}

\author{
Fendy Prasetyo Nugroho ${ }^{1)}$, Arvin Triyoga Wisnutomo ${ }^{2)}$ \\ Studio XI Technology Industry Laboratory, CV Jaya Kreatifindo Surakarta ${ }^{1)}$ \\ D3 Teknik Informatika, Sekolah Vokasi, Universitas Sebelas Maret Surakarta ${ }^{2)}$ \\ vendyscenter@yahoo.com ${ }^{1)}$, arvintriyoga@ student.uns.ac.id ${ }^{2)}$
}

\begin{abstract}
Abstrak
Pada era Revolusi Industri 4.0 saat ini, investasi teknologi informasi merupakan hal penting agar sebuah produk digital mempunyai kekuatan atau daya saing di lingkungan bisnis yang dinamis dan kompetitif. Beralihnya dunia analog menuju digital menambah variasi dalam visualisasi sebuah karya. Perkembangan pengetahuan teknologi informasi multimedia dan animasi yang dimanfaatkan sebagai media promosi melalui Virtual Reality Technology saat ini juga semakin beragam dan akan terus berkembang dengan cepat. Virtual Reality Technology menjadi alternatif dikarenakan penyajian pesan yang disampaikan sangat interaktif karena memberikan lingkungan yang imersif sebagai daya tarik pengguna. Penelitian ini dilakukan untuk membantu melakukan analisa dan mengukur kelayakan investasi teknologi informasi sebuah produk digital Virtual Reality Technology menggunakan metode Information Economics dengan proses bisnis yang akan memberikan kontribusi secara non-finansial (intangible) pada domain teknologi. Dari hasil analisis domain teknologi yang telah dilakukan dapat menunjukkan bahwa pada sebuah produk digital yang memanfaatkan Virtual Reality Technology memiliki nilai keuntungan investasi yang baik dan memberikan manfaat yang lebih besar daripada risiko yang akan didapatkan.
\end{abstract}

Kata Kunci: Teknologi Informasi, Virtual Reality, Investasi TI, Information Economics

\section{PENDAHULUAN}

Perkembangan pada pengetahuan teknologi multimedia dan animasi saat ini semakin beragam dan terus berkembang dengan cepat karena mendapat perhatian khusus sebagai sebuah teknologi praktis yang difungsikan untuk meningkatkan promosi serta meningkatkan nilai investasi dengan baik pada sebuah produk digital. Peningkatan kualitas sebuah produk digital merupakan kenyataan yang harus diprioritaskan untuk dilakukan secara terencana, terarah, intensif, efektif, efisien dan bermanfaat. (Nugroho FP, 2017)

Kemajuan teknologi multimedia yang semakin pesat membuat sebuah media informasi atau promosi kini beralih ke teknologi informasi Virtual Reality Technology. (Saurik, dkk. 2018). Virtual Reality adalah pemunculan gambar tiga dimensi yang dibuat komputer sehingga terlihat nyata dengan dukungan peralatan tertentu, yang menjadikan pengguna seolaholah terlibat langsung secara fisik dalam lingkungan tersebut (Saurik, dkk., 2018).
Virtual Reality menjadi konsep berinteraksi yang cukup mudah digunakan seiring dengan perkembangan teknologi.

Investasi teknologi informasi merupakan hal yang penting agar perusahaan mempunyai daya saing di lingkungan bisnis yang dinamis dan kompetitif. Tentunya peningkatan belanja teknologi informasi harus dibarengi dengan peningkatan kualitas penilaian investasi teknologi informasi. Menurut survei (Dekleva, 2005), sekitar 51\% perusahaan tidak pernah melakukan evaluasi investasi teknologi informasi, bahkan terdapat sekitar $68 \%$ perusahaan tidak membandingkan manfaat yang diperoleh dengan besaran nilai investasi yang telah dikeluarkan perusahaan.

Selanjutnya tahun 2017, menurut penelitian (Ni Made \& Frederik, 2017) beberapa survei menunjukkan penilaian investasi teknologi informasi merupakan sebuah masalah di banyak perusahaan karena lebih dari 86\% eksekutif bisnis menggunakan metode penilaian keuangan Return on Investment (ROI) untuk menilai investasi teknologi informasi, sedangkan hanya $18 \%$ 
dari 456 Chief Information Officer (CIO) yang menggunakan ROI, akibat lebih memilih penilaian dari segi ketepatan waktu dan biaya proyek serta hasil manfaatnya. Berdasarkan hal tersebut, untuk mengetahui manfaat dari investasi teknologi informasi dibutuhkan sebuah perencanaan proyek teknologi informasi yang maksimal.

Salah satu kerangka kerja yang dapat digunakan untuk memaksimalkan perencanaan proyek teknologi informasi dengan menghitung nilai kontribusi investasi yaitu menggunakan metode Information Economics (IE) yang dimana memiliki dua kategori yaitu domain bisnis dan domain teknologi yang dapat membantu menganalisis manfaat dari biaya investasi proyek teknologi informasi. Analisis menggunakan domain teknologi pada metode Information Economics dapat membantu untuk menentukan nilai sebuah investasi yang dapat mendatangkan keuntungan yang lebih besar dan diperlukan untuk memperhitungkan nilainilai ekonomis yang akan diperoleh dari investasi teknologi informasi pada tahun yang sedang berjalan maupun tahun-tahun yang akan datang.

Berdasarkan tinjauan penelitian yang telah ada sebelumnya, maka penelitian ini dilakukan untuk membantu menganalisa dan mengukur kelayakan investasi teknologi informasi pada sebuah produk digital Virtual Reality Technology dengan metode Information Economics pada domain teknologi yang dimana proses bisnis berfokus pada kontribusi produk secara non-finansial untuk menunjukkan bahwa pada sebuah produk digital yang memanfaatkan Virtual Reality Technology memiliki nilai keuntungan investasi yang baik dan memberikan manfaat yang lebih besar daripada risiko yang didapatkan.

\section{METODE PENELITIAN}

Tahap ini dilakukan pengambilan data mengenai segala bentuk informasi yang berkaitan dengan investasi Virtual Reality Technology. Kemudian melakukan analisis data, analisis manfaat serta perhitungan atau pembobotan nilai pada domain teknologi. Proses pengambilan data yang digunakan dalam penelitian ini dilakukan dengan tiga teknik berikut:

a. Wawancara
Teknik ini dilakukan dengan cara melakukan tanya jawab secara langsung untuk mendapatkan informasi dan bahan data yang diperlukan.

b. Observasi

Melakukan observasi terhadap objek yang diteliti yaitu menganalisa teknologi informasi dan mencari data yang telah memiliki aturan baku untuk mendapatkan informasi yang belum didapat dari metode wawancara.

c. Dokumentasi

Teknik dokumentasi dilakukan dengan melakukan review dari dokumen yang diperoleh serta mengenai rencana investasi teknologi informasi yang akan dilakukan.

\section{TINJAUAN PUSTAKA}

(Zulkifli, 2016) penelitian dengan judul "Implementasi Metode Information Economics (IE) Untuk Menganalisis Manfaat Investasi Sistem Dan Teknologi Informasi USNI" menyimpulkan bahwa Metode Informaton Economics merupakan perluasan dari metode Traditional Cost Benefit Analysis, yang juga melihat dari Value Linking dan Value Acceleration. Metode untuk melakukan penilaian terhadap kelayakan investasi sistem dan teknologi infomasi adalah pengukuran benefit dari suatu implementasi SI\&IT-USNI dengan Information Economics.

(Fajar, dkk., 2017) penelitian dengan judul "Analisis Kelayakan Anggaran Investasi Teknologi Informasi dengan Analisis Cost Benefit" memaparkan bahwa pada penelitian terdahulu disebutkan menganalisis CostBenefit pada pengembangan teknologi jaringan pada PT. Indo Super Kencana dengan Metode information economics. Hasil penelitian menyatakan bahwa proyek jaringan WAN memiliki nilai manfaat lebih tinggi dibandingkan proyek jaringan W-LAN.

(Mauladani, 2017) Teknologi informasi adalah suatu teknologi yang digunakan untuk mengolah data, termasuk memproses, mendapatkan, menyusun, menyimpan, memanipulasi data dalam berbagai cara untuk menghasilkan informasi yang berkualitas, yaitu informasi yang relevan, akurat dan tepat waktu, yang digunakan untuk keperluan pribadi, bisnis, dan pemerintahan serta merupakan informasi yang strategis untuk 
pengambilan keputusan. Teknologi informasi memainkan peranan penting dalam perekayasaan ulang sebagian besar proses bisnis yang dapat bermanfaat untuk semua pengguna.

(Mauladani, 2017) menerangkan bahwa investasi teknologi informasi merupakan keputusan yang diambil oleh perusahaan untuk meningkatkan sumber daya dari pengeluaran biaya yang nyata dari pemanfaatan teknologi informasi dengan harapan manfaat dari pengeluaran biaya tersebut dapat mencapai target nilai keuntungan dari apa yang diharapkan. (Rembang, dkk., 2012) Lebih lanjut diterangkan bahwa investasi teknologi informasi juga dapat dijelaskan sebagai total biaya yang dikeluarkan untuk lifecycle keseluruhan proyek ataupun bagian dari proyek yang melibatkan teknologi informasi, termasuk didalamnya biaya operasional setelah proyek berlangsung (post project operating cost). Biaya yang dikeluarkan tidak lagi dihitung sebagai sebuah nilai investasi ketika investasi yang dilakukan diganti atau dibatalkan dengan alasan apapun. Penerapan teknologi informasi pada sebuah produk digital di bidang bisnis dapat menciptakan peningkatan competitive advantage yang dimiliki oleh sebuah perusahaan.

(Mauladani, 2017) Peran penggunaan teknologi informasi secara lebih rinci terdapat pada Gambar 1.

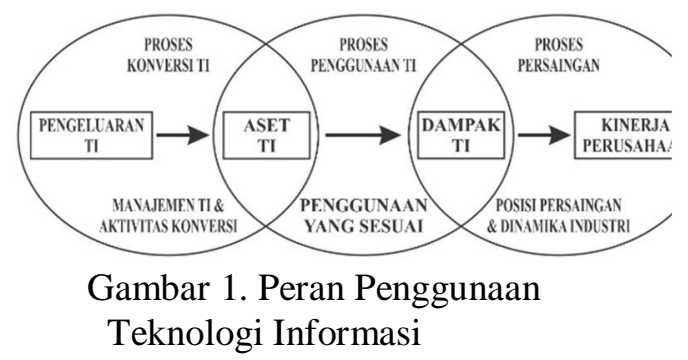

Information Economics (IE) merupakan sekumpulan alat hitung yang berfungsi untuk mengukur manfaat dan biaya dari proyek teknologi informasi, yang dalam analisis ini dilihat dari dua sisi, yakni bisnis dan teknologi. (Sibarani, 2014) Metode Information Economics adalah suatu metode perhitungan yang merupakan pengembangan dari analisis cost-benefit tradisional. Metode ini dirancang dan diperkenalkan oleh Marilyn M. Parker pada tahun 1985. Information economics digunakan untuk analisis biaya dan manfaat, mengkuantitatifkan biaya proyek teknologi informasi. Secara eksplisit, information economics dengan evaluasi alternatif mengenai investasi sistem informasi melakukan identifikasi, evaluasi, scoring dan pemberian ranking, faktor positif (manfaat) dan faktor negatif (ketidakpastian atau risiko) yang potensial dari adanya investasi teknologi informasi yang dilakukan. (Santoso, 2014)

Pendekatan non-finansial dalam analisis Information Economics menilai keuntungan sebuah investasi teknologi informasi yang bersifat tidak nyata (intangible benefit) namun memiliki dampak positif bagi perusahaan dan secara tidak langsung memiliki pengaruh terhadap keuntungan perusahaan tersebut.

(Mauladani, 2017) Memaparkan bahwa dalam analisis pendekatan non-finansial pada analisis Information Economics dapat dilihat dari dua domain penilaian, yakni domain bisnis dan domain teknologi. Menurut (Rembang, dkk., 2012) dalam domain bisnis terdiri dari lima elemen, yakni strategic match, competitive advantage, management information support, competitive response dan project or organizational risk. Sedangkan aspek manfaat investasi teknologi informasi dalam domain teknologi meliputi empat elemen, yakni:

a. Strategic IS Architecture, menjelaskan mengenai manfaat proyek atau investasi teknologi informasi yang diukur melalui tingkat kesesuaian proyek terhadap perencanaan proyek atau investasi secara keseluruhan.

b. Defitional Uncertainty, menjelaskan mengenai manfaat proyek atau investasi sistem informasi atau teknologi informasi yang diukur melalui besarnya unsur ketidakpastian akibat perubahan dari target.

c. Technical Uncertainty, menjelaskan mengenai manfaat proyek atau investasi teknologi informasi yang diukur melalui besarnya ketergantungan proyek terhadap sumber daya yang dimiliki, seperti keahlian dan kemampuan, perangkat lunak, perangkat keras dan sistem yang digunakan.

d. Infrastucture Risk, menjelaskan mengenai manfaat proyek atau investasi sistem informasi atau teknologi informasi yang diukur melalui kepentingan investasi non proyek untuk mengakomodasi adanya proyek teknologi 
informasi supaya dapat berjalan dengan baik.

\section{HASIL DAN PEMBAHASAN}

(Sudrajat, dkk., 2019) Analisis investasi teknologi informasi merupakan sebuah analisis yang ditujukan untuk mengetahui apakah investasi TI yang telah diterapkan dalam perusahaan telah memberikan manfaat nyata (tangible benefit) yaitu manfaat yang berpengaruh langsung terhadap perusahaan seperti pengurangan pemakaian kertas, manfaat yang mengacu pada peningkatan efisiensi kinerja (quasi-tangible benefit), dan manfaat tidak nyata (intangible benefit) yaitu manfaat yang berdampak positif terhadap perusahaan tetapi tidak berpengaruh langsung pada keuntungan. Metode yang digunakan dalam menilai kelayakan investasi TI ini menggunakan metode Information Economics yang dikembangkan oleh Marilyn M. Parker pada tahun 1985 dan di revisi pada tahun 1996. Menurut Parker untuk menghitung tangible benefit dapat mengunakan metode analisis biaya manfaat.

Dalam menganalisis intangible benefit mengunakan penilaian analisis dua domain yaitu domain bisnis dan domain teknologi. Domain Teknologi membahas pada risiko dan keuntungan yang muncul dari penggunaan teknologi pada sebuah proyek. Terdapat nilai dan resiko teknologi informasi dilihat dari domain teknologi yang memungkinkan untuk dikuantifikasi secara finansial karena nilainilai dan resiko-resiko tersebut umumnya bersifat intangible. Dalam kerangka kerja dengan metode Information Economics, perlu dilakukan pembobotan atas nilai dan resiko yang ada. Untuk mengetahui pembobotan atas nilai dan resiko maka diperlukan alat bantu berupa kuesioner yang diberikan kepada ahli (expert judgement) Virtual Reality sebagai acuan dasar pembobotan.

\section{a. Pembobotan Domain Teknologi}

Faktor-faktor dalam domain teknologi dibagi menjadi tiga kategori yaitu: Strategic Values, Competitive Strategy Risk, dan Organizational Risk and Uncertainty. Data yang digunakan adalah sample data yang diperoleh dari penelitian yang telah dilakukan sebelumnya berdasarkan hasil diskusi dengan para pakar (expert judgement) sebayak empat orang secara langsung. Hasil yang didapat dari wawancara dengan para ahli dapat dilihat pada Tabel 1.

Tabel 1. Tabel Pembobotan

\begin{tabular}{|l|c|c|c|c|c|}
\hline \multirow{2}{*}{$\begin{array}{c}\text { Faktor Domain } \\
\text { Teknologi }\end{array}$} & \multicolumn{3}{|c|}{ Skor Para Ahli } & $\begin{array}{c}\text { Skor } \\
\text { Rata } \\
\text { Rata }\end{array}$ \\
\cline { 2 - 5 } $\begin{array}{l}\text { Strategic IS } \\
\text { Architecture }\end{array}$ & 5 & 4 & 5 & 4 & 4,50 \\
\hline $\begin{array}{l}\text { Definitional } \\
\text { Uncertainty }\end{array}$ & 2 & 3 & 2 & 4 & 2,75 \\
\hline $\begin{array}{l}\text { Technical } \\
\text { Uncertainty }\end{array}$ & 5 & 5 & 5 & 4 & 4,75 \\
\hline $\begin{array}{l}\text { Keterampilan yang } \\
\text { dibutuhkan }\end{array}$ & 5 & 5 & 5 & 5 & 5,00 \\
\hline $\begin{array}{l}\text { Ketergantungan } \\
\text { perangkat keras }\end{array}$ & 5 & 5 & 5 & 5 & 5,00 \\
\hline $\begin{array}{l}\text { Ketergantungan } \\
\text { perangkat lunak }\end{array}$ & 5 & 5 & 5 & 5 & 5,00 \\
\hline$\bullet$ Perangkat Aplikasi & 5 & 2 & 4 & 2,75 \\
\hline $\begin{array}{l}\text { IS Insfrastructure } \\
\text { Risk }\end{array}$ & 3 & 2 & & \\
\hline
\end{tabular}

\section{b. Analisis Biaya Investasi}

Membuat sebuah produk teknologi informasi Virtual Reality Technology dibutuhkan sejumlah dana yang disebut dengan biaya investasi. Biaya investasi meliputi biaya perangkat keras dan perangkat lunak. Asumsi nilai total biaya investasi pada teknologi informasi Virtual Reality Technology yaitu sebesar Rp 135.000.000,00 dengan rincian berikut:

Biaya perangkat keras merupakan semua biaya yang berhubungan dengan pembelian peralatan fisik untuk membangun produk teknologi informasi Virtual Reality sebesar Rp 95.000.000,00 dengan rincian pada Tabel 2.

Tabel 2. Investasi Perangkat Keras

\begin{tabular}{|c|l|l|}
\hline No. & \multicolumn{1}{|c|}{ Hardware } & \multicolumn{1}{|c|}{ Spesifikasi } \\
\hline 1. & VR Headset & Oculus Quest 2 \\
\hline 2. & Treadmill VR & Virtuix Omni One \\
\hline 3. & $\begin{array}{l}\text { Personal } \\
\text { Computer }\end{array}$ & $\begin{array}{l}\text { Cube Gaming Weiss V2.0 } \\
\text { Black, AMD Ryzen 5 3600x }\end{array}$ \\
\hline 4. & Monitor & Dell 24" \\
\hline 5. & Smart TV & Mi TV 4 43" \\
\hline 6. & Bracket & Standing TV 43" Bracket \\
\hline
\end{tabular}

Biaya perangkat lunak merupakan semua biaya yang berhubungan dengan pembelian software untuk server. Investasi awal yang dilakukan dalam perangkat lunak sebesar Rp 50.000.000,00.

\section{a. Analisis Biaya Berjalan}

Selain adanya biaya investasi awal, juga terdapat biaya berjalan yang dihitung 
selama 5 tahun mendatang dengan kenaikan beban biaya $5 \%$ per tahun. Dalam pengembangan teknologi informasi Virtual Reality Technology biaya berjalan meliputi biaya pemeliharaan (maintenance), biaya tenaga kerja dan biaya listrik. Nominal biaya berjalan dapat dilihat pada Tabel 3 .

Tabel 3. Biaya Berjalan (dalam juta rupiah)

\begin{tabular}{|c|c|c|c|c|c|}
\hline Ket. & Th. 1 & Th. 2 & Th. 3 & Th. 4 & Th. 5 \\
\hline A & 135 & 135 & 135 & 135 & 135 \\
\hline B & 15 & 15,75 & 16,54 & 17,37 & 18,24 \\
\hline C & 10 & 10,5 & 11,025 & 11,58 & 12,16 \\
\hline Total & $\mathbf{1 6 0}$ & $\mathbf{1 6 1 , 2 5}$ & $\mathbf{1 6 2 , 5 7}$ & $\mathbf{1 6 3 , 9 5}$ & $\mathbf{1 6 5 , 4}$ \\
\hline
\end{tabular}

Keterangan:

A : Biaya Maintenance

B : Biaya Tenaga Kerja

C : Biaya Listrik

\section{b. Analisis Manfaat Quasi-Tangible \\ 1) Value Linking (VL)}

Value Linking merupakan analisis dalam mengevaluasi secara finansial dan dihubungkan dengan faktor-faktor dalam domain bisnis dan domain teknologi yang memberikan dampak terhadap peningkatan kerja dan produktifitas. Beberapa dampak yang menghasilkan peningkatan kinerja sebagai manfaat intangible antara lain: peningkatan produktivitas karyawan dan pengurangan human error. Perhitungan manfaat Value Linking dapat dilihat pada Tabel 4.

Tabel 4. Value Linking

(dalam juta rupiah)

\begin{tabular}{|c|c|c|c|c|c|}
\hline Ket. & Th. 1 & Th. 2 & Th. 3 & Th. 4 & Th. 5 \\
\hline D & 335 & 351,7 & 369,4 & 387,8 & 407,2 \\
\hline E & 175 & 183,7 & 192,9 & 202,5 & 212,7 \\
\hline Total & $\mathbf{5 1 0}$ & $\mathbf{5 3 5 , 4}$ & $\mathbf{5 6 2 , 3}$ & $\mathbf{5 9 0 , 3}$ & $\mathbf{6 1 9 , 9}$ \\
\hline
\end{tabular}

Keterangan:

D : Peningkatan Produktivitas Karyawan

E : Pengurangan Human Error

\section{2) Value Acceleration (VA)}

Implementasi teknologi informasi

Virtual Reality ini memberikan dampak percepatan dalam menyelesaikan suatu kegiatan (time dependency) yang diidentifikasikan sebagai intagible benefit dalam mempercepat pencapaian tujuan dan menghitung efektivitas biaya atau penghematan biaya yang dikeluarkan. Value Acceleration dilihat pada Tabel 5.

Tabel 5. Value Acceleration (dalam juta rupiah)

\begin{tabular}{|c|c|c|c|c|c|}
\hline Ket. & Th. 1 & Th. 2 & Th. 3 & Th. $\mathbf{4}$ & Th. 5 \\
\hline F & 135 & 135 & 135 & 135 & 135 \\
\hline G & 120 & 126 & 132.3 & 139 & 146 \\
\hline Total & $\mathbf{2 5 5}$ & $\mathbf{2 6 1}$ & $\mathbf{2 6 7 , 3}$ & $\mathbf{2 7 4}$ & $\mathbf{2 8 1}$ \\
\hline
\end{tabular}

Keterangan:

F : Percepatan Waktu Proses

G : Efektivitas Biaya Promosi

\section{3) Value Restructuring (VR)}

Elemen Value Restructuring yaitu peningkatan produktivitas suatu kegiatan yang dapat diukur akibat adanya teknologi informasi Virtual Reality yang diharapkan dapat meningkatkan produktivitas setiap pengguna serta efektivitas waktu kerja dengan mengurangi kegiatan yang bernilai rendah atau yang kurang produktif. Value Restructuring dapat dilihat pada Tabel 6.

Tabel 6. Value Restructuring (dalam juta rupiah)

\begin{tabular}{|c|c|c|c|c|c|}
\hline Ket. & Th. 1 & Th. 2 & Th. 3 & Th. 4 & Th. 5 \\
\hline H & 15 & 15,75 & 16,6 & 17,3 & 18,2 \\
\hline I & 12 & 12,6 & 13,2 & 13,9 & 14,6 \\
\hline Total & $\mathbf{2 7}$ & $\mathbf{2 8 , 3 5}$ & $\mathbf{2 9 , 8}$ & $\mathbf{3 1 , 2}$ & $\mathbf{3 2 , 8}$ \\
\hline
\end{tabular}

Keterangan:

$\mathrm{H}$ : Peningkatan Produktivitas Karyawan

I : Peningkatan Kemudahan Komunikasi

\section{4) Innovation Valuation (IV)}

Innovation Valuation menjelaskan mengenai manfaat dari inovasi teknologi informasi yang menjadi penggerak dalam perubahan strategi bisnis dan produk. Ketika pertama kali diimplementasikan maka belum akan mendapatkan nilai.

Dari seluruh perhitungan analisis manfaat quasi-tangible dapat disimpulkan bahwa rincian nilai manfaat quasi-tangible ditunjukkan pada Tabel 7.

Tabel 7. Rincian Manfaat Quasi-Tangible (dalam juta rupiah)

\begin{tabular}{|c|c|c|c|c|c|}
\hline Ket. & Th. 1 & Th. 2 & Th. 3 & Th. 4 & Th. 5 \\
\hline J & 510 & 535,4 & 562,3 & 590,3 & 619,9 \\
\hline K & 255 & 261 & 267,3 & 274 & 281 \\
\hline L & 27 & 28,35 & 29,8 & 31,2 & 32,8 \\
\hline M & 0 & 0 & 0 & 0 & 0 \\
\hline
\end{tabular}

Keterangan:

$\mathrm{J}$ : Value Linking

$\mathrm{K}$ : Value Acceleration

$\mathrm{L}$ : Value Restructuring

$\mathrm{M}$ : Innovation Valuation

Masing-masing nilai manfaat tersebut akan digunakan untuk perhitungan enhanced 
ROI yang bertujuan untuk mengetahui besaran ROI setelah adanya manfaat quasi-tangible yang dihasilkan.

\section{c. Perhitungan Skor Enhanced ROI}

Untuk mendapatkan skor enhanced ROI, besaran keseluruhan manfaat finansial dijumlahkan dengan persamaan berikut:

Enhanced ROI $=$
Tangible Benefit $/$ Pengurangan Biaya
Operasional $+V L+V A+V R+I V$

Sehingga akan mendapatkan nilai akhir pada Perhitungan Skor Enhanced ROI pada Tabel 8 .

Tabel 8. Perhitungan Skor Enhanced ROI (dalam juta rupiah)

\begin{tabular}{|c|c|c|c|c|c|}
\hline Ket. & Th. 1 & Th. 2 & Th. 3 & Th. 4 & $\begin{array}{c}\text { Th. } \\
\mathbf{5}\end{array}$ \\
\hline N & $\mathbf{1 6 0}$ & $\mathbf{1 6 1 , 2 5}$ & $\mathbf{1 6 2 , 5 7}$ & $\mathbf{1 6 3 , 9 5}$ & $\mathbf{1 6 5 ,}$ \\
& & & & & $\mathbf{4}$ \\
\hline J & 510 & 535,4 & 562,3 & 590,3 & $\begin{array}{c}619, \\
9\end{array}$ \\
\hline K & 255 & 261 & 267,3 & 274 & 281 \\
\hline L & 27 & 28,35 & 29,8 & 31,2 & 32,8 \\
\hline M & 0 & 0 & 0 & 0 & 0 \\
\hline Total & $\mathbf{9 5 2}$ & $\mathbf{9 8 6}$ & $\mathbf{1 0 2 1 , 9}$ & $\mathbf{1 0 5 9 , 4}$ & $\mathbf{1 0 9 9 , 1}$ \\
\hline \multicolumn{7}{|r|}{ Total Keseluruhan: $\mathbf{5 1 1 8 , 5}$} \\
\hline
\end{tabular}

Keterangan:

$\mathrm{J}$ : Value Linking

$\mathrm{K}$ : Value Acceleration

L : Value Restructuring

$\mathrm{M}$ : Innovation Valuation

$\mathrm{N}$ : Pengurangan Biaya

Menghitung simple ROI menggunakan rumus:

$$
\text { Simple ROI = (Net Cash Flow }: \text { Periode }
$$$$
\text { Tahun : Biaya Awal) x 100\% }
$$

Simple ROI sebesar :

Simple $R O I=(5.118 .500 .000: 5$ : $135.000 .000) \times 100 \%$

$$
=758,3 \%
$$

\section{d. Analisis Domain Teknologi}

Setelah melakukan pembobotan domain bisnis seperti pada Tabel. 1 dan melakukan analisis biaya investasi, analisis biaya berjalan dan analisis manfaat Quasi-Tangible, maka selanjutnya dapat dilakukan analisis terhadap domain teknologi sebagai berikut:

\section{1) Strategic IS Architecture}

Faktor ini digunakan untuk mengetahui derajat manfaat proyek atau investasi teknologi informasi Virtual Reality yang diukur melalui tingkat kesesuaian proyek terhadap perencanaan proyek atau investasi secara keseluruhan. Berdasarkan pada tabel hasil penilaian diperoleh skor rata-rata Strategic IS Architecture $=4,50$ (dengan skor minimum 0 dan maksimum 5), maka dapat dikatakan bahwa investasi teknologi informasi Virtual Reality memiliki tingkat kelayakan yang tinggi dari faktor Strategic IS Architecture.

\section{2) Definitional Uncertainty}

Digunakan untuk mengetahui manfaat investasi teknologi informasi Virtual Reality yang diukur dari besarnya unsur ketidakpastian akibat perubahan dari target. Faktor ini menilai bahwa semakin rendah skor yang diberikan, maka semakin kecil risiko dari implementasi teknologi informasi Virtual Reality serta dapat dikatakan semakin layak teknologi informasi tersebut untuk diinvestasikan. Skor rata-rata yang diperoleh Definitional Uncertainty $=2,75$ (dengan skor minimum 0 dan maksimum 5), maka dapat disimpulkan bahwa investasi pengembangan proyek teknologi Virtual Reality memiliki tingkat kelayakan yang rendah dari faktor Definitional Uncertainty.

\section{3) Technical Uncertainty}

Faktor ini digunakan untuk mengetahui manfaat proyek atau investasi teknologi informasi Virtual Reality yang diukur melalui nilai ketergantungan proyek terhadap sumber daya yang dimiliki seperti, keterampilan yang dibutuhkan dengan skor rata-rata $=4,75$, perangkat keras $=5,00$, perangkat lunak $=$ 5,00 dan perangkat aplikasi $=5,00$ (dengan nilai minimum 0 dan maksimum 5), sehingga Technical Uncertainty merupakan faktor risiko dalam implementasi teknologi informasi karena semakin kecil skor yang diperoleh, semakin kecil pula risikonya dan dikatakan layak investasi.

\section{4) IS Insfrastructure Risk}

Faktor ini digunakan untuk menguji mengenai manfaat proyek atau investasi teknologi informasi Virtual Reality yang diukur melalui kepentingan investasi nonproyek untuk mengakomodasi adanya proyek. 
IS Insfrastructure Risk merupakan salah satu faktor risiko sehingga semakin kecil skor yang diperoleh menunjukkan semakin kecilnya risiko implementasi teknologi informasi dan dapat dinyatakan layak untuk diinvestasikan. Dengan skor rata-rata IS Insfrastructure Risk = 2,75 (skor minimum 0 dan maksimum 5), maka teknologi informasi Virtual Reality memiliki tingkat kelayakan cukup tinggi.

\section{c. KESIMPULAN DAN SARAN}

Dari analisa penelitian tentang teknologi informasi Virtual Reality yang telah dilakukan menggunakan analisa Domain Teknologi pada metode Information Economics maka, kesimpulan yang dapat disampaikan adalah sebagai berikut:

a. Hasil analisis menggunakan domain teknologi menunjukkan teknologi informasi Virtual Reality bisa dikembangkan dan layak investasi.

b. Manfaat Tangible: mengurangi biaya operasional dan efisiensi tenaga kerja.

c. Manfaat Quasi-Tangible: mengurangi risiko pekerjaan berat, mempercepat pengerjaan, peningkatan produktifitas.

d. Terjadi penghematan langsung/biaya operasional.

e. Manfaat Value Linking berupa berkurangnya risiko pekerjaan berat, dapat mendukung pencegahan biaya.

f. Manfaat Value Acceleration berupa mempercepat proses promosi dan dapat memberikan percepatan proses pencegahan biaya tiap tahun.

g. Manfaat Value Restructuring berupa peningkatan produktivitas yang dapat mengurangi biaya non produktif.

Saran yang dapat diberikan pada penelitian tentang teknologi informasi Virtual Reality yang telah dilakukan menggunakan analisa Domain Teknologi pada metode Information Economics adalah sebagai berikut:

a. Melakukan analisa menggunakan Domain Bisnis untuk dapat menemukan kelayakan investasi Teknologi Informasi Virtual Reality.

b. Analisis corporate value harus dilakukan secara dalam berdasarkan komponen metode information economics untuk memudahkan penentuan posisi kuadran.
Hal tersebut akan sangat mempengaruhi hasil akhir dari skor proyek.

c. Penggalian manfaat dari investasi teknologi informasi khususnya pada aspek finansial hendaknya dilakukan lebih mendalam.

\section{d. REFERENSI}

Dekleva, Sasha. 2005. Justifying Investment in IT. Journal of information Technology Management Vol. XVI, No. 3.

Fajar H, dkk. 2017. Analisis Kelayakan Anggaran Investasi Teknologi Informasi dengan Analisis Cost Benefit. Jurnal Keuangan dan Perbankan, Vol. 14 No. 1.

Herman TT Saurik, Devi Dwi P., Jeremiah Irawan H. 2018. Teknologi Virtual Reality Untuk Media Informasi Kampus. Jurnal Teknologi Informasi dan Ilmu Komputer. Vol. 6, No. 1.

Mauladani, Razi. 2017. Analisis Investasi Sistem Informasi e-Ketenagakerjaan Dengan Menggunakan Metode Information Economics pada PT. Mahakam Kencana Intan Padi. ITS.

Nugroho, Fendy P. 2017. Implementasi Augmented Reality Technology (ART) Sebagai Media Promosi Tentang Museum Purbakala Sangiran Kabupaten Sragen. Yogya: Universitas Amikom Yogyakarta.

Rembang, C. S., Kaunang, S. T., Karouw, S., \& Lantang, O. A. 2012. Analisis Efektifitas Investasi Proyek Teknologi Informasi Dengan Menggunakan Metode Information Economics. Jurnal Teknik Informatika Universitas Sam Ratulangi.

Santoso Leo W. 2014. Analisis Investasi Sistem Informasi Dengan Mengguna-kan Domain Teknologi - Metode Information Economics. Konferensi Nasional SI.

Sibarani, A. J. 2014. Analisis Sistem Informasi Rumah Sakit Menggunakan Metode Information Economics. Jurnal Informatika Vol. 8, No. 2.

Sudrajat Budi, Rudianto. 2019. Analisis Kelayakan Investasi Teknologi Informasi Menggunakan Metode Information Economics. Jurnal Informatika dan RPL. Vol. 1 No. 2.

Zulkifli. 2016. Implementasi Metode Information Economics (IE) Untuk Menganalisis Manfaat Investasi Sistem \& 
Jurnal Informa : Jurnal Penelitian dan Pengabdian Masyarakat. p-ISSN : 2442-7942, e-ISSN 2716-5051

Volume 7 Nomor 1 Juni 2021

Teknologi Informasi USNI. Jurnal Satya Informatika Vol. 1 No. 2. 